\title{
Inteligencia artificial y periodismo [presentación del monográfico]
}

\section{Artificial intelligence (Al) and journalism [monograph presentation]}

\section{Coordinadores científicos / Scientific coordinators}

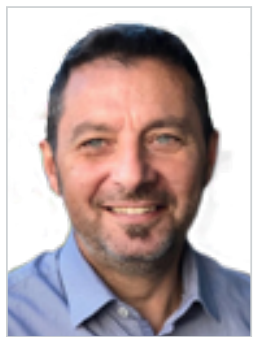

José Miguel Túñez López. Profesor titular del Departamento de Ciencias de la Comunicación de la Universidade de Santiago de Compostela. Miembro del Grupo de Investigación Novos Medios, de la USC, e IP2 en el proyecto "Indicadores de gobernanza, financiación, rendición de cuentas, innovación, calidad y servicio público de las RTV europeas" (Ref. CSO2015-66543-P). Director del programa de Doctorado en Comunicación e Información Contemporánea, en la USC. Codirector de la Revista de la Asociación Española de Investigación de la Comunicación (RAEIC). Su producción científica más reciente incluye "Automatización, bots y algoritmos en la redacción de noticias. Impacto y calidad del periodismo artificial" (Revista Latina de Comunicación Social, 2019, 74, 1411-1433) y "Uso de bots y algoritmos para automatizar la redacción de noticias: percepción y actitudes de los periodistas en España" (El profesional de la información, 2018, v27, n4, 750-758).

Professor of the Department of Communication Science at the Universidade de Santiago de Compostela. He is also a member of the Research Group Novos Medios at USC, and principal investigator (PI2) on the project entitled "Indicadores de gobernanza, financiación, rendición de cuentas, innovación, calidad y servicio público de las RTV europeos" (Indicators of governance, finance, accounting, innovation, quality and public service of European Radio and Television) (Ref. CSO2015-66543-P). Professor Túñez López is also Director of the Doctorate Programme of Contemporary Communication and Information at USC, as well as Co-director of the Journal of the Spanish Association for Communication Research (RAEIC). His most recent scientific work includes Communication: Innovation \& Quality (2018, Springer), and "Uso de bots y algoritmos para automatizar la redacción de noticias: percepción y actitudes de los periodistas en España" (Use of bots and algorithms to automate news writing: perception and attitudes of journalists in Spain) (El profesional de la información, 2018, v27, n4, 750-758).

Universidad de Santiago de Compostela, España

miguel.tunez@usc.es

ORCID:0000-0002-5036-9143

\section{Palabras clave:}

Inteligencia artificial, periodismo, bots, algoritmos, comunicación digital.

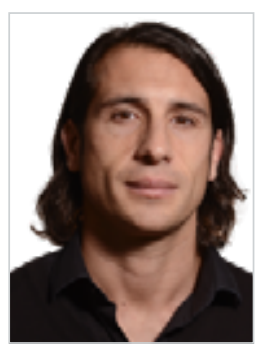

Santiago Tejedor Calvo. Profesor agregado y director del Departamento de Periodismo y Ciencias de la Comunicación de la Universidad Autónoma de Barcelona. Doctor en Periodismo y CC. de la Comunicación por la UAB (Premio Extraordinario de Doctorado, 2006) y Doctor en Ingeniería de Proyectos por la UPC. Coordinador del Gabinete de Comunicación y Educación. Sus líneas de investigación se centran en el ciberperiodismo, la convergencia mediática y las nuevas narrativas transmedia. Ha sido investigador visitante en la Universidad Pontificia Bolivariana de Medellín (Colombia), la Universidad Latina de San José (Costa Rica) y la Universidad Centroamericana de Managua (Nicaragua). Posee el título honorífico "Egregius Educator", otorgado por el Consejo Superior de Dirección de la Universidad de Ciencias Comerciales (UCC) de Managua (Nicaragua).

Associate Professor and Director of the Department of Journalism and Communication Science at the Autonomous University of Barcelona (UAB). He holds a PhD in Journalism and Communication Science, also from UAB (Extraordinary Doctorate Award, 2006), and a PhD in Project Engineering from UPC. He is Coordinator of the Communication and Education Committee. His lines of research focus on cyber journalism, media convergence and new transmedia narratives. In addition, Professor Tejedor Calvo has been a visiting researcher at the Pontifical Bolivariana University of Medellín (Colombia), Universidad Latina de San José (Costa Rica), and Universidad Centroamericana de Managua (Nicaragua). He holds the honorary title of "Egregius Educator", awarded by the Superior Board of Directors of the University of Commercial Sciences (UCC) of Managua (Nicaragua).

Universidad Autónoma de Barcelona, España

santiago.tejedor@uab.cat

ORCID: 0000-0002-5539-9800

\section{Keywords:}

Artificial intelligence, journalism, bots, algorithms, digital communication.

Cómo citar este artículo:

Túñez López, J. M.; Tejedor Calvo, S. (2019). Inteligencia artificial y periodismo [presentación del monográfico]. Doxa Comunicación, 29, pp. 163-168.

https://doi.org/10.31921/doxacom.n29a8 


\section{Presentación}

Los avances tecnológicos han posibilitado un especial encuentro entre el periodismo y la inteligencia artificial (IA). Numerosos medios de comunicación-de aquí y de allí-han impulsado sus primeras experiencias en un escenario tan nuevo como novedoso. La incorporación de robots en las redacciones acumula ya una experiencia consistente. Desde la revista Forbes, a través de un sistema que denominan Narrative Science, hasta iniciativas de la agencia de noticias estadounidense Associated Press o los diarios The New York Times, Los Angeles Times, Le Monde o, en el escenario español, los proyectos pioneros de El Confidencial y Sport, a los que rápidamente su sumaron iniciativas de un largo listado de medios: El Independiente, El Español, Televisión Española (TVE), la Agencia EFE y la televisión autonómica de Cataluña $T V 3$, entre otros.

El avance de la irrupción de la IA en la producción informativa podría ejemplificarse con las 20.000 noticias que la empresa Narrativa elaboró para El Periódico de Catalunya a partir de los datos oficiales del recuento de votos en la noche electoral del 10 de noviembre, algo impensable para ser desarrollado por una redacción humana. Los dirigentes de la empresa calculan que los algoritmos que ellos han diseñado para empresas de Europa, América y Asia habrían elaborado en ese mes (noviembre de 2019) más de un millón de textos informativos.

En este escenario de cambios tan acelerados, la investigación y la divulgación desde la academia, en colaboración con diferentes medios y proyectos, resulta decisiva. Este monográfico, titulado "Inteligencia artificial y periodismo" responde justamente a necesidad de observar, describir, analizar, comparar y evaluar las posibilidades, los retos y los desafíos que emergen en el prolífico intercambio entre la comunicación, el periodismo, las historias, la tecnología y

\section{Presentation}

Technological advances have made possible a special convergence between journalism and artificial intelligence (AI). Numerous communication media from various locations have carried out their first experiences with this confluence in a scenario as new as it is innovative. The incorporation of robots into newsrooms has already experienced considerable implementation. Some of these entities include Forbes magazine with a system called Narrative Science, the American news agency Associated Press with its own initiatives, and newspapers such as The New York Times, Los Angeles Times, and Le Monde. In Spain, the pioneering projects of El Confidencial and Sport must also be mentioned, to which initiatives from a long list of other Spanish media were quickly added, including El Independiente, El Español, Televisión Española (TVE), Agencia EFE, and Autonomous Television of Catalonia (TV3). The rapid advance of AI in the production of information is exemplified by the 20,000 news items that the company Narrativa prepared for El Periódico de Catalunya from the official data of the vote count on election night on November 10th, a feat that would have been unthinkable from a newsroom using only human effort. The company's top management estimate that the algorithms they had designed for companies in Europe, America and Asia would have produced more than one million informative texts in that month (November 2019).

In an environment of such rapid change, it is vital to include research and dissemination from academia in collaboration with various media and other projects. This monograph, entitled "Artificial Intelligence and Journalism," is focused precisely on the need to observe, describe, analyse, compare and evaluate the possibilities, challenges and hurdles that are emerging in the prolific exchange between communication, journalism, stories, technology, and the 
la denominada "inteligencia exhibida por máquinas" o inteligencia artificial.

Esta rama de las ciencias computacionales se encarga de estudiar y valorar las posibilidades de que una máquina desarrolle tareas propias de las personas. Todo ello partiendo de dos de sus características más representativas: el razonamiento y la conducta. Algunos autores han definido la IA como la posibilidad de que las máquinas puedan automatizar actividades como la toma de decisiones, la definición de estrategias de actuación o la capacidad para aprender a resolver un problema. En definitiva: la posibilidad de las máquinas para poder "pensar" de forma autónoma. Se trata de un "territorio" rico en posibilidades que abarca numerosas áreas de nuestras sociedades. La salud, la educación, el ocio..., son algunos de los ámbitos que se han visto revolucionados por estos avances tecnológicos.

La comunicación y el periodismo son igualmente campos con gran proyección y expectativa de ideación de nuevos desarrollos. Robots que crean mensajes a partir de datos, máquinas que facilitan la cobertura y el mapeo de zonas asoladas por catástrofes naturales o incluso dispositivos capaces de monitorear y detectar accidentes de tránsito. Sin embargo, es solo el principio. En periodismo, la IA se centra en el fact-checking para certificar la veracidad de hechos y relatos, en la detección de temas, y en la elaboración de textos simulando la redacción informativa de un humano, incluso con apuntes interpretativos. Ya no sólo se generan textos basados en datos, sino que se diseñan programas informáticos con autonomía para la interpretación de esos datos de modo que la máquina relacione, proponga y cree un relato. La tendencia actual es que los algoritmos generen o bien textos cortos descriptivos publicables, o bien propuestas más elaboradas que sirvan de base para el toque final y personal del periodista. Igualmente, se trabaja para que se puedan generar piezas audiovisuales a partir del reconocimiento de imágenes y de sentimientos. so-called "intelligence exhibited by machines," or artificial intelligence.

This branch of computer science is responsible for studying and assessing the possibility that a machine might be able to carry out tasks that until now have been performed only by people. This idea is based on two of the most symbolic characteristics of human beings: reasoning and behaviour. Some authors have defined AI as the possibility that machines might have the capacity to automate activities such as decision-making, definition of strategic plans, and the ability to learn or solve problems- in short, machines might to be able to "think" autonomously. This is a "territory" rich with opportunities that cover many areas of society. Health, education, leisure, and so on, are some of the areas that have been revolutionized by these technological advances.

Communication and journalism are also fields with a great future and is expected to undergo ideation for new developments. Robots that create messages from data, machines that facilitate coverage and mapping of areas devastated by natural disasters, and even devices capable of monitoring and detecting traffic accidents. However, this is only the beginning. In journalism, AIfocuses on fact-checking to verify the accuracy of facts and stories, on the detection of topics, and the creation of texts simulating the informative writing of a human being, even with interpretative notes. Not only can texts be generated from data, but computer programs are also designed to autonomously interpret those data, so the machine relates the data, proposes, and then creates a story. The current trend is for algorithms to generate either short descriptive texts that can be published, or more elaborate proposals that serve as the basis for the journalist's final revision and personal touch. They also work in such a way that audio-visual pieces can be generated from the recognition of images and feelings. 
El avance de la IA y su impacto en la sociedad es una preocupación global. En España, el Gobierno diseñó una estrategia para la IA en $\mathrm{I}+\mathrm{D}+\mathrm{i}$ que establecía seis prioridades para el periodo 2012-2018: 1. Crear una estructura organizativa que permita desarrollar un sistema de I+D+i en IA y medir su impacto; 2. Fijar áreas estratégicas en las que concentrar el esfuerzo de acciones vinculadas a la IA; 3. Favorecer la transferencia del conocimiento y su retorno a la sociedad; 4. Promover la formación y la profesionalización en torno a la IA; 5. Desarrollar lo que se denomina "un ecosistema digital de datos" y valorizar las infraestructuras disponibles; y 6. Prestar atención a los aspectos éticos vinculados a IA y a la investigación.

Estas prioridades, fijadas por el grupo de trabajo creado en 2018, “deberán ser desarrolladas en iniciativas y actividades definidas y financiadas a través de los Planes Estatales de Ciencia, Tecnología e Innovación (PECTI), movilizando las sinergias entre los distintos niveles de la administración pública y mediante el codesarrollo del sector público y privado", para lo que se trabaja en el diseño de un Plan Nacional que permita "crear un ecosistema con sistemas inteligentes multitarea”.

Los expertos afirman que, en un futuro muy cercano, todas las actividades profesionales que puedan ser automatizadas se automatizarán. Para algunos, es un gran logro. Para otros, la semilla de una amenaza. Y para todos, un desafío intelectual que nos invita a la investigación, la reflexión y el debate a través, entre otras acciones, de especiales monográficos como el que impulsa la revista Doxa Comunicación y que ha logrado reunir un acervo de textos de gran valor diagnóstico, explicativo e incluso predictivo. Se trata de una colección de artículos de investigación que, desde diferentes áreas y miradas, nos aproximan a ese "lugar" de encuentro (para algunos, de colisión) entre el periodismo y la inteligencia artificial.
The advance of AI and its impact on society is a global concern. In Spain, the Government designed a strategy for using AI in RDI, which established six priorities for the 2012-2018 period as follows: 1 . To create an organizational structure that allows for the development of an AI - RDI system, and for the measurement of its impact; 2 . To establish strategic areas in which efforts should be concentrated on actions related to AI; 3. To promote the transfer of knowledge and its return to society; 4 . To promote the training and professionalization related to AI; 5. To develop what is called " $a$ digital data ecosystem" and assess the available infrastructures; and 6. To pay attention to ethical aspects related to AI and research in this field.

These priorities were established by Grupo de Trabajo (The Work Group), created in 2018, and "should be developed for initiatives and activities defined and financed through the State Plan for Science, Technology and Innovation (PECTI), mobilizing synergies among different levels of public administration and co-development involving public and private sectors". For this purpose, work is being carried out on the design of a National Plan that will allow for the "creation of an ecosystem with intelligent multitasking systems". Experts claim that in the very near future all professional activities that are capable of being automated will be automated. For some, this is a great achievement. For others, the seed of a threat. Moreover, among other actions that need to be taken, this is an intellectual hurdle that everyone needs to overcome, which compels us to research, reflect, and debate through special monographs such as the one that has been promoted by the journal Doxa Comunicacion, which has managed to gather a collection of texts of significant diagnostic, explanatory and even predictive value. This is a collection of research articles from different areas and views, which bring us closer to the "point" of convergence (for some, of collision) between journalism and artificial intelligence. 
Cesibel Valdivieso-Abad y Tiziano Bonini, con un artículo titulado "Automatización inteligente en la gestión de la comunicación", presentan un trabajo sobre la automatización inteligente centrada en el ámbito de la gestión de la comunicación de las organizaciones. Por su parte, Jesús Miguel Flores Vivar presenta un artículo titulado "Inteligencia artificial y periodismo: diluyendo el impacto de la desinformación y las noticias falsas a través de los bots", que analiza los principales desarrollos de robots utilizados para minimizar el impacto de las fake news. El trabajo de María José Ufarte Saavedra y Juan Luis Mandredi, titulado "Algoritmos y bots aplicados al periodismo. El caso de Narrativa Inteligencia Artificial: estructura, producción y calidad informativa", analiza la organización, los procesos de trabajo y la calidad de las noticias elaboradas por Narrativa Inteligencia Artificial, la principal empresa del país que redacta textos periodísticos a través de un software.

El monográfico incluye también el trabajo de José Luis Rojas y Carlos Toural que, bajo el título de "Periodismo deportivo automatizado. Estudio de caso de AnaFut, el bot desarrollado por El Confidencial para la escritura de crónicas de fútbol", incide en el estado embrionario del desarrollo y la aplicación de la inteligencia artificial al periodismo, especialmente, al deportivo. A continuación, Renato Essenfelder, João Canavilhas, Haline Costa Maia, Ricardo Jorge Pinto aportan el trabajo titulado "Automatización de textos periodísticos en la televisión brasileña: Estudio de caso del sistema AIDA (Globo-Brasil)", en el que estudian un proyecto de la televisión brasileña Globo denominado AIDA, con el objetivo de buscar en la automatización de contenidos informativos una respuesta para evitar errores y ambigüedades en las noticias. Como colofón, Jesús Segarra-Saavedra, F. J. Cristófol, Alba María Martínez Sala han publicado el artículo "Inteligencia artificial (IA) aplicada a la documentación informativa y redacción periodística deportiva. El caso de BeSoccer", que tiene como principal objetivo buscar refe-
Cesibel Valdivieso-Abad and Tiziano Bonini, with an article entitled "Intelligent automation in communication management", present a paper on intelligent automation focused on the field of communication management of organizations. For his part, Jesús Miguel Flores Vivar presents an article with the name "Artificial intelligence and journalism: diluting the impact of disinformation and fake news through bots", which analyses the major developments of robots used to minimize the impact of fake news.

The work of María José Ufarte Saavedra and Juan Luis Mandredi, entitled "Algorithms and bots applied to journalism. The case of Narrativa Inteligencia Artificial: structure, production and informative quality", analyses the organization, work processes and quality of news created by Narrativa Inteligencia Artificial, which is the main company in Spain that writes journalistic texts using software.

The monograph also includes the work of José Luis Rojas and Carlos Toural, who under the title of "Automated Sports Journalism. The AnaFut case study, the bot developed by El Confidencial for writing football match reports", focuses on the embryonic stage of the development and application of artificial intelligence to journalism, especially sports journalism. Next, Renato Essenfelder, João Canavilhas, Haline Costa Maia, and Ricardo Jorge Pinto have contributed an article entitled "Automated News in Brazilian television: a case study of the AIDA system (Globo-Brazil)". In this paper, they study the project known as AIDA from Globo Brazilian television with the objective of searching for answers within the automation of informative content in order to avoid errors and ambiguities in the news. To conclude, Jesús Segarra-Saavedra, F. J. Cristófol, and Alba María Martínez Sala have published an article with the title of "Artificial intelligence (AI) applied to informative documentation and journalistic sports writing. The case of BeSoccer". The main objective of the study is to search for theoretical references to AI applied to journalism, as well as to become familiar with 
rentes teóricos sobre la IA aplicada al periodismo, así como conocer BeSoccer a través del estudio del caso y las entrevistas en profundidad a su CEO y al responsable de marketing. En su investigación, los autores identifican nuevas formas de producción de contenidos de periodismo aplicado al ámbito deportivo, así como el perfil del nuevo profesional del periodismo vinculado estrechamente al big data y la IA.

De este modo, el conjunto de seis artículos presenta una interesante reflexión sobre las oportunidades, las ventajas y los aportes de la combinación entre la IA y el periodismo, al tiempo que invita a reflexionar sobre la esencia del ejercicio periodístico y la necesidad de fortalecer el rol y el valor del periodista dentro de un escenario de marcada presencia tecnológica. El monográfico aporta interesantes conclusiones, pero al mismo tiempo estimula la necesidad de una reflexión, que ha de ser perenne desde la academia y desde la industria, alrededor de aspectos tales como las condiciones laborales, los nuevos roles profesionales, el impacto y la necesidad de redefinir la formación de los futuros profesionales del periodismo, el rol de las facultades y escuelas de comunicación, la pertinencia de foros de reflexión sobre estas temáticas y el componente ético que acompaña a este tipo de avances.
BeSoccer through the case study and in-depth interviews with its CEO and marketing manager. In their research, the authors identify new ways of producing journalistic content applied to the sports field, and also examine the profile of the new journalistic professional closely linked to big data and AI.

Therefore, this collection of six articles presents an interesting reflection on the opportunities, advantages and contributions resulting from the blending of $A I$ and journalism, while encouraging reflection on the essence of journalistic practice and the need to strengthen the role and value of the journalist within a scenario symbolized by the presence of technology. The monograph provides interesting conclusions, but at the same time awakens the need for reflection, which must be continual from both academia and industry on aspects such as working conditions, new professional roles, the impact of this technology, and the need to redefine the training of future journalistic professionals. Moreover, the role of faculties and schools of communication, the relevance of forums for reflection on these issues, and the ethical component that accompanies this type of progress must be considered as well. 